CONF-970455-

\begin{abstract}
G. E. Fuchs
April 1997

DISTRUBUTION OF THIS DOCLMENT IS UNEMUTED

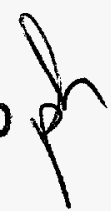

MASTER

NOTICE

This report was prepared as an account of work sponsored by the United States Government. Neither the United States, nor the United States Department of Energy, nor any of their employees, nor any of their contractors, subcontractors, or their employees, makes any warranty, express or implied, or assumes any legal liability or responsibility for the accuracy, completeness or usefulness of any information, apparatus, product or process disclosed, or represents that its use would not infringe privately owned rights.
\end{abstract}




\section{DISCLAIMER}

This report was prepared as an account of work sponsored by an agency of the United States Government. Neither the United States Goverament oor any agency thereof, nor any of their employees, makes any warranty, express or implied, or assumes any legal liability or responsibility for the accuracy, completeress, or usefulness of any information, apparatus, produch, or process disclosed, or represents that its use would not infringe privately owned rights. Reference herein to any specific commercial product, process, or service by trade name, trademarte inanufacturer, or otherwise does not necessarily constitute or imply its endorsement, recommendation, or favoring by the United States Government or any agency thereof. The views and opinions of authors expressed herein do not necessarily state or reflect those of the United States Government or any agency thereof. 


\section{DISCLAIMER}

Portions of this document may be illegible in electronic image products. Images are produced from the best available original document. 


\title{
Multi-step Wrought Processing of TiAl-Based Alloys
}

\author{
G.E. Fuchs \\ Lockheed Martin Company \\ P.O. Box 1072 \\ Schenectady, NY 12301-1072
}

\begin{abstract}
$\underline{\text { Abstract }}$
Wrought processing will likely be needed for fabrication of a variety of TiAl-based alloy structural components. Laboratory and development work has usually relied on one-step forging to produce test material. Attempts to scale-up TiAl-based alloy processing has indicated that multi-step wrought processing is necessary. The purpose of this study was to examine potential multi-step processing routes, such as two-step isothermal forging and extrusion + isothermal forging. The effects of processing ( $/ \mathrm{M}$ versus $\mathrm{P} / \mathrm{M}$ ), intermediate recrystallization heat treatments and processing route on the tensile and creep properties of Ti- $48 \mathrm{Al}-2 \mathrm{Nb}-2 \mathrm{Cr}$ alloys were examined. The results of the testing were then compared to samples from the same heats of materials processed by one-step'routes. Finally, by evaluating the effect of processing on microstructure and properties, optimized and potentially lower cost processing routes could be identified.
\end{abstract}

\section{Background}

The development of alloys based on the intermetallic compound, TiAl, has been possible due to the better understanding of the effects of alloying additions, heat treatment and thermo-mechanical processing (TMP) on their microstructure and properties (1-5). Both cast and wrought processing approaches have been evaluated for production of gas turbine hardware. Due to the severe solidification segregation, larger parts or components with greatly varying-cross-sections may require wrought processing. Microstructural refinement is not possible in cast alloys and homogeneous microstructure cannot be produced in cast products in all cases. Therefore, wrought processing is considered necessary for a variety of prospective components. In order to reduce the cost of wrought processing, commercial techniques must be utilized to produce large forging billets that can be cut into smaller preforms $(6,7)$. Therefore, wrought processing often means multiple step processing.

In order to evaluate realistic processing routes, it is necessary to process even the laboratory scale material with multiple processing steps. The purpose of this study is to examine both ingot metallurgy (I/M) and powder metallurgy $(\mathrm{P} / \mathrm{M})$ processing techniques with multiple step wrought processing. Wrought processing approaches used in this study were extrusion and isothermal forging. The alloy selected for this study was the $\mathrm{Ti}-48 \mathrm{Al}-2 \mathrm{Nb}-2 \mathrm{Cr}$ (at\%) alloy. Note that unless otherwise indicated, all compositions are in atomic $\%$.

\section{Experimental Procedures}

A single $25 \mathrm{Kg}$ heat of $\mathrm{Ti}-47 \mathrm{Al}-2 \mathrm{Nb}-2 \mathrm{Cr}$ powder was argon gas atomized at Crucible Research Center 
(CRC), Oakdale, PA and sieved to -35 mesh $(<500 \mu \mathrm{m})$ powder yield. The composition of the powder is presented in Table 1 . The powder was canned in a cylindrical commercial purity (CP) Ti can measuring 12.7 $\mathrm{cm}$ diameter $\times 20 \mathrm{~cm}$ long. The CP-Ti can was evacuated, sealed, wrapped in Ta foil, and canned again in a mild steel extrusion can. The canned powder was extruded at $1300^{\circ} \mathrm{C}$ with a reduction ratio of $4.3: 1$ and a ram speed of $200 \mathrm{~cm} /$ minute at the GE Corporate Research and Development Center (Table 2). After extrusion, the bar was slow cooled in vermiculite. Metallographic and forging samples $(5 \mathrm{~cm}$ diameter $\times 5 \mathrm{~cm}$ long) were prepared from the extruded bar. None of the forging samples were heat treated prior to isothermal forging. Extruded samples were isothermally forged at Ladish Company, Inc., Cudahy, WI, at $1175^{\circ} \mathrm{C}$ at a strain rate of $0.1 / \mathrm{min}$ with a $75 \%$ height reduction (Table 2 ).

A second single $25 \mathrm{Kg}$ heat of Ti-47Al-2Nb-2Cr was vacuum induction skull melted and split poured into two graphite molds at Duriron Company, Inc., Dayton, OH (Tables 1 and 2). Approximately half of the heat was poured into a $12.7 \mathrm{~cm}$ diameter mold, and the remainder of the heat was cast into a $7 \mathrm{~cm}$ diameter mold. Both ingots were hot isostatically pressed (HIP'ed) to eliminate shrinkage porosity $\left(1260^{\circ} \mathrm{C} / 172 \mathrm{MPa} / 4 \mathrm{hrs}\right)$ and were homogenized at $1425^{\circ} \mathrm{C}$ for 30 minutes. The larger diameter ingot was wrapped in Ta foil and canned in a mild steel extrusion can. The canned ingot was extruded at $1300^{\circ} \mathrm{C}$ with a reduction ratio of $4.3: 1$ and a ram speed of $200 \mathrm{~cm} / \mathrm{minute}$ at the GE Corporate Research and Development Center (Table 2). After extrusion, the bar was slow cooled in vermiculite. Metallographic and forging samples $(5 \mathrm{~cm}$ diameter $\mathrm{x} 5 \mathrm{~cm}$ long) were prepared from the extrudéd bar. Some of the forging samples were heat treated $\left(1200^{\circ} \mathrm{C} / 48 \mathrm{hrs}\right)$ prior to isothermal forging to recrystallize the microstructure. Extruded samples were isothermally forged at Ladish Company, Inc., Cudahy, WI, at $1175^{\circ} \mathrm{C}$ at a strain rate of $0.1 / \mathrm{min}$ with a $75 \%$ height reduction (Table 2 ).

The remaining $7 \mathrm{~cm}$ diameter ingot was sectioned into samples either $10 \mathrm{~cm}$ high or $5 \mathrm{~cm}$ high. The $7 \mathrm{~cm}$ diameter $\mathrm{x} 10 \mathrm{~cm}$ forging mults were used to evaluate two-step isothermal forging. These samples were given an initial isothermal forging step $\left(1175^{\circ} \mathrm{C} / 0.1 \mathrm{~min}^{-1} / 50 \%\right)$ to breakdown the coarse grained homogenized microstructure. Approximately half of the forged samples were given a $1200^{\circ} \mathrm{C} / 48 \mathrm{hr}$ recrystallization heat treatment prior to the final forging step $\left(1175^{\circ} \mathrm{C} / 0.1 \mathrm{~min}^{-1} / 75 \%\right)$. The remaining unrecrystallized samples were also given the same final forging step, but were still in the as-forged condition from the first breakdown forging step. The $7 \mathrm{~cm}$ diameter $\times 5 \mathrm{~cm}$ samples were used to evaluate one-step forging, and given the sample final forging step $\left(1175^{\circ} \mathrm{C} / 0.1 \mathrm{~min}^{-1} / 75 \%\right)$ as the two-step forging samples (Table 2).

Blanks ( $1.25 \mathrm{~cm}$ diameter $\mathrm{x} 7 \mathrm{~cm}$ long) for mechanical testing were removed from the forged pancakes and heat treated to produce a near-lamellar microstructure $\left(1350^{\circ} \mathrm{C} / 2 \mathrm{hrs} / \mathrm{AC}+900^{\circ} \mathrm{C} / 6 \mathrm{hrs} / \mathrm{AC}\right)$. Threaded mechanical test samples were low stress ground to final dimensions with a $4.5 \mathrm{~mm}$ diameter $\times 12.7 \mathrm{~mm}$ long gage section. The tensile properties were determined in the temperature range of $25^{\circ}-1000^{\circ} \mathrm{C}$ in air at an initial strain rate of $1.67 \times 10^{-3} / \mathrm{sec}$. The creep properties were determined at $700^{\circ} \mathrm{C}$ and $850^{\circ} \mathrm{C}$ in air at stresses ranging from 103-310 MPa under constant load conditions. Fracture surfaces of selected samples were examined by scanning electron microscopy (SEM) and a limited number of samples were evaluated by transmission electron microscopy (TEM) techniques.

\section{$\underline{\text { Results }}$}

The extrusion forces required for breakthrough and steady state running of the $\mathrm{I} / \mathrm{M}$ and $\mathrm{P} / \mathrm{M}$ extrusions 
are presented in Table 2. Note that the $\mathrm{P} / \mathrm{M}$ samples required significantly lower pressures for extrusion. In addition, the peak forging stresses are shown in Table 2. The I/M and P/M Extrude + Forge samples exhibit lower forging stresses than the two-step forged $\mathrm{I} / \mathrm{M}$ samples and significantly lower stresses than the one-step forged I/M samples. Little or no effect of processing (e.g., I/M versus $\mathrm{P} / \mathrm{M}$ ) on the peak forging stresses was observed in the Extrude + Forge processing route. The recrystallization heat treatment also appears to have very little effect on forging stresses for both the Extrude + Forge and the two-step forging routes.

\section{Microstructures}

The $1425^{\circ} \mathrm{C} / 30 \mathrm{~min}$ heat treatment of the $\mathrm{I} / \mathrm{M}$ samples resulted in a fully lamellar, coarse grained microstructure. This microstructure represents the starting condition for the extrusion and the one-step forging samples. After extrusion, the P/M samples exhibited a fine grained equiaxed microstructure predominantly made-up of equiaxed $\gamma$ grains with $\alpha_{2}$ present, as both small equiaxed grains at $\gamma$ grain boundaries and as lamellae in the limited number of $\gamma / \alpha_{2}$ lamellar grains. Although not obvious from the optical metallographic observations, a limited amount of small equiaxed $\beta$ phase grains would also be expected. The $1 / M$ extruded samples exhibited a highly deformed lamellar microstructure with some evidence of a limited amount of dynamic recrystallization from the extrusion process. Heat treatment of the $\mathrm{I} / \mathrm{M}$ extruded sample at $1200^{\circ} \mathrm{C} / 48 \mathrm{hrs}$ results in recrystallization of the deformed microstructure.

The microstructure of the I/M two-step forging samples after the initial breakdown forging $\left(1175^{\circ} \mathrm{C} / 0.1 \mathrm{~min}^{-1} / 50 \%\right)$ was a highly deformed lamellar structure with significant amounts of dynamically recrystallized $\gamma$ grains. A smaller amount of dynamic recrystallization than in the extruded $\mathrm{I} / \mathrm{M}$ samples is observed in the forged mults. The lower strain rate of the forging operation allows for more time for dynamic recrystallization to occur, but the deformation is occurring at lower temperature and a smaller amount of deformation is being imparted to the sample. Heat treatment of the I/M breakdown forged sample at $1200^{\circ} \mathrm{C} / 48 \mathrm{hrs}$ results in recrystallization of the deformed microstructure.

The heat treated microstructures after final forging are shown in Figures 1-3. All of the samples exhibited near-lamellar microstructures comprised predominantly of lamellar $\gamma / \alpha_{2}$ grains with relatively coarse grain size. Processing appeared to have very little effect on grain size. All of the samples appeared to have very similar grain sizes.

\section{Tensile Properties}

At room temperature, all of the alloys exhibited very similar yield strengths (Figures 4 and 5). No effect of processing on yield strength could be observed. The highest ductilities were observed in the P/MExtrude+Forge and the two-step forged I/M material. The I/M-Extrude+Forge and the one-step forge I/M materials exhibited the lowest ductilities. The modulus determined from the strip charts did not display any differences as a function of processing history, so no obvious texturing was believed to occur.

At $500^{\circ} \mathrm{C}$, all of the samples exhibited equivalent yield strengths with no obvious effect of processing. The yield strengths did decrease slightly from the strength levels observed at room temperature. The ductility of the samples increased from that observed at room temperature, and very little effect of processing was observed. The I/M samples did appear to exhibit slightly higher ductility. 
At $700^{\circ} \mathrm{C}$, all of the samples continued to exhibit strengths that were similar with no effect of processing apparent. The yield strengths observed at $700^{\circ} \mathrm{C}$ were similar to those observed at $500^{\circ} \mathrm{C}$. The ductility, in most cases, increased from the $500^{\circ} \mathrm{C}$ levels. However, the $\mathrm{I} / \mathrm{M}$-Extrude+Forge samples appeared to exhibit less ductility than the other I/M-Forged or the P/M-Extrude+Forge materials.

Increasing the test temperature to $850^{\circ} \mathrm{C}$ had virtually no effect on the yield strength of any of the materials. The ductility, however, increased dramatically when the test temperature was raised from $700^{\circ} \mathrm{C}$ to $850^{\circ} \mathrm{C}$. The highest ductilities were observed in the $\mathrm{I} / \mathrm{M}$ samples and some samples exhibited more that $100 \%$ elongation. $\mathrm{P} / \mathrm{M}$ samples exhibited slightly lower ductilities, however, the $\mathrm{P} / \mathrm{M}$ samples did exhibit at least $70 \%$ elongation at $850^{\circ} \mathrm{C}$.

Further increasing the test temperature to $1000^{\circ} \mathrm{C}$ resulted in significant decreases in yield strength, but had only limited effects on ductility. No obvious effect of processing on yield strength could be discerned, since very similar yield strengths were observed for all of the materials conditions tested. Increasing the test temperature to $1000^{\circ} \mathrm{C}$ resulted in decreased ductility in the I/M-Extrude+Forge samples, but appeared to have very little impact on the ductility of the one- and two-step forged I/M samples. The P/M-Extrude+Forge samples exhibited tensile ductilities at $1000^{\circ} \mathrm{C}$ very similar to those observed at $850^{\circ} \mathrm{C}$.

\section{Creep Rupture Properties}

The creep rupture properties of the samples were determined at $700^{\circ} \mathrm{C}$ and $850^{\circ} \mathrm{C}$ in air under constant load condition (Figure 6). The I/M and P/M Extrude+Forge samples exhibited similar creep properties regardless of processing history. Similarly, the I/M one- and two-step forged samples exhibited approximately equivalent creep resistance. However, the Extrude+Forge samples possessed greater creep resistance than the $\mathrm{I} / \mathrm{M}$ one and two-step forged samples (Figure 7).

\section{Fractography}

Samples tested at temperatures up to and including $700^{\circ} \mathrm{C}$ exhibited a mixed mode cleavage (i.e., interlamellar/translamellar/intergranular) fracture. No obvious effects of processing were observed. At test temperatures greater than $700^{\circ} \mathrm{C}$, increasing amounts of ductile, dimpled fracture were observed. Again, processing appeared to have little or no effect on fracture morphology.

\section{$\underline{\text { Discussion }}$}

Although the processing routes utilized in this study were very different, the resulting microstructure and tensile properties were very similar. Multiple processing steps (i.e., Extrude+Forge or two-step forging) did result in materials with improved tensile ductilities under most conditions. However, among the materials processed with multiple hot working operations, no significant differences in tensile properties were observed. The creep properties of the samples were determined at $700^{\circ} \mathrm{C}$ and $850^{\circ} \mathrm{C}$. Although the tensile properties were very similar at these temperatures, regardless of the processing condition, significant differences in creep properties were observed. Both the $\mathrm{I} / \mathrm{M}$ and the $\mathrm{P} / \mathrm{M}$ Extrude+Forge samples exhibited equivalent creep properties, with the I/M samples perhaps possessing slightly greater creep resistance. All of the one-step and 
two-step I/M forging samples exhibited similar creep resistance. However, when comparing the Extrude+Forge samples and the one-step and two-step forged materials significant and consistent differences were observed. In all cases, the Extrude+Forge materials exhibited greater creep resistance than the one-step and two-step forged materials.

The creep resistance does not appear to be a function of total deformation imposed by the processing route. The total deformation of the Extrude+Forge processing route is greater than that of the two-step forge and the one-step forge processes. The extrusion process represents a true strain deformation of 1.468 and the final forging operation (1.39 true strain) results in a total true strain deformation for the Extrude+Forge process of 2.85. Both the two-step and the one-step forged samples exhibited very similar creep resistance. The twostep forging operation represents a total true strain deformation of 2.08 , and the one-step forging is only a total true strain deformation of 1.39 Since increasing the true strain of deformation from 1.39 to 2.08 by going from one-step to two-step forging operations does not appear to affect creep resistance, it seems unlikely that further increases in total strain would result in increased creep resistance.

The increased creep resistance observed in the Extrude+Forge samples may be due to the more homogeneous deformation that occurs by changing the strain path during processing. Multiple forging operations do not change the deformation strain path unless the workpiece is rotated. In all cases, during this study, the workpiece orientation was maintained with the strain path parallel to the long axis of the cylindrical ingot. However, the extrusion process and the forging operation do not have parallel strain paths and will result in more uniform deformation and microstructures.

\section{Conclusions}

Wrought TiAl-based alloy samples were produced by several multi-step processing techniques. After heat treatment to produce near-lamellar microstructures, no significant effects on the resulting microstructure and tensile properties were observed. Creep resistance, however, was dependent on the processing route. Both the I/M and P/M Extrude+Forge samples exhibited creep resistance superior to the one-step and the two-step forged $\mathrm{I} / \mathrm{M}$ samples. This difference in creep resistance may be due to a more uniform microstructure produced by the changes in the strain path during processing.

\section{Acknowledgements}

The author would like to thank S. Floreen for his technical support and helpful discussions. In addition, the substantial efforts of J.P. Beckman (CRC), J.R. Hughes (GE CR\&D) and R.R. Hoffman (Ladish Co.) and D.U. Furrer (Ladish Co.) are greatly appreciated.

\section{References}

1.) Y.-W. Kim, J. Metals, 41 (1989), pp. 24-30.

2.) Y.-W. Kim and D.M. Dimiduk, J. Metals, 43, (1991), pp. 40-47.

3.) Y.-W. Kim, J. Metals, 46, (1994), pp. 30-40. 
4.) G.E. Fuchs, Gamma Titanium Aluminides, Eds. Y.-W. Kim, R. Wagner and M. Yamaguchi, TMS, Warrendale, PA, (1995), p. 563-570.

5.) D.U. Furrer, R.R. Hoffman and Y.-W. Kim, Gamma Titanium Aluminides, Eds. Y.-W. Kim, R. Wagner and M. Yamaguchi, TMS, Warrendale, PA, (1995), p. 611-618.

6.) P.L. Martin, S.K. Jain and M.A. Stucke, Gamma Titanium Aluminides, Eds. Y.-W. Kim, R. Wagner and M. Yamaguchi, TMS, Warrendale, PA, (1995), p. 727-736.

7.) P.L. Martin and D.A. Hardwick, Titanium '95; Science and Technology, Eds. P.A. Blackinsop, W.J. Evans and H.M. Flower, TIM, (1996), p. 168-175.

\section{Table 1 - Composition of $\mathbf{I} / \mathbf{M}$ and $P / M$ Materials}

\begin{tabular}{|c|c|c|c|c|}
\hline \multirow[b]{2}{*}{ Element } & \multicolumn{2}{|c|}{ Ingot Metallurgy } & \multicolumn{2}{|c|}{ Powder Metallurgy } \\
\hline & Atomic \% & Weight \% & Atomic \% & Weight \% \\
\hline $\mathrm{Ti}$ & $\mathrm{Bal}$ & $\mathrm{Bal}$ & $\mathrm{Bal}$ & $\mathrm{Bal}$ \\
\hline $\mathrm{Al}$ & 47.17 & 32.7 & 47.33 & 33.22 \\
\hline $\mathrm{Nb}$ & 1.97 & 4.7 & 1.96 & 4.70 \\
\hline $\mathrm{Cr}$ & 1.95 & 2.6 & 1.95 & 2.62 \\
\hline $\mathrm{C}(\mathrm{ppm})$ & 100 & 300 & 120 & 390 \\
\hline $\mathrm{O}_{2}(\mathrm{ppm})$ & 1165 & 479 & 1720 & 710 \\
\hline $\mathrm{H}_{2}(\mathrm{ppm})$ & 425 & 11 & 1420 & 37 \\
\hline $\mathrm{N}_{2}(\mathrm{ppm})$ & 275 & 99 & 190 & 190 \\
\hline
\end{tabular}

Table 2 - Processing History and Grain Size

All Alloys Based on Ti-48Al-2Nb-2Cr

All Samples Given Near-Lamellar Heat Treatment: $1350^{\circ} \mathrm{C} / 2 \mathrm{hrs} / \mathrm{AC}+900^{\circ} \mathrm{C} / 6 \mathrm{hrs} / \mathrm{AC}$

All I/M samples homogenized $\left(1440^{\circ} \mathrm{C} / 20 \mathrm{~min}\right)$ prior to hot working

Extrusion: $1300^{\circ} \mathrm{C} / 4.3: 1 / \mathrm{SC}$, Forge (isothermal): $1175^{\circ} \mathrm{C} / 75 \%$ (unless otherwise noted) $/ 0.1 \mathrm{~min}^{-1}$ RXN HT - Recrystallization Heat Treatment $-1200^{\circ} \mathrm{C} / 48 \mathrm{hrs}$

Alloy ID

TA-156F1L

TA-163F1L

TA-163FEL

TA-159F1L

TA-159F2L

TA-159F5L
P/M: Extrude+Forge

Processing History

I/M: Extrude+RXN HT+Forge

I/M: Extrude+Forge

I/M: Forge $(50 \%)+\mathrm{RXN}$ HT+Forge

I/M: Forge $(50 \%)+$ Forge

I/M: Forge
Extrusion

Total

Deformation (True Strain)

2.85

2.85

2.85

2.08

2.08

1.39
Peak

Final

Forging

Stress

$\mathrm{MPa}$

124

128

131

138

143

226 


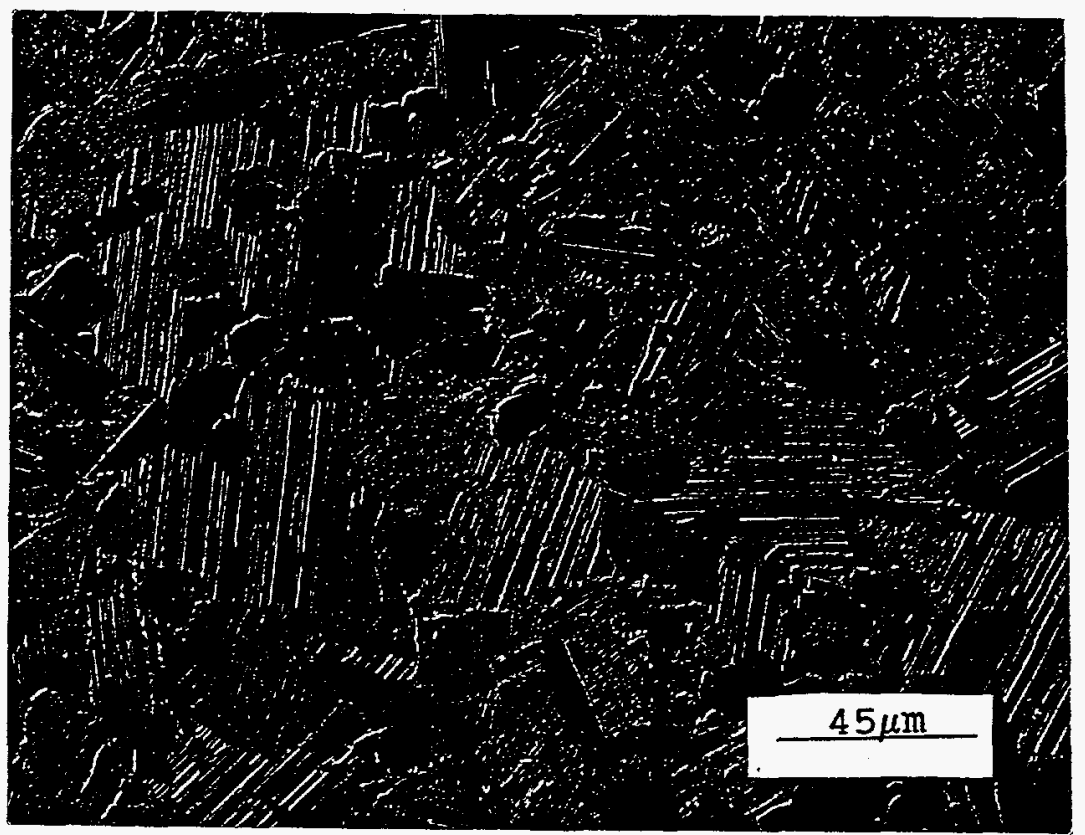

Figure 1 - Optical photomicrograph showing the near-lamellar microstructure of the heat treated $\left(1350^{\circ} \mathrm{C} / 2 \mathrm{hrs} / \mathrm{AC}+900^{\circ} \mathrm{C} / 6 \mathrm{hrs} / \mathrm{AC}\right) \mathrm{P} / \mathrm{M}$ Extrude + Forge (TA-156) sample.

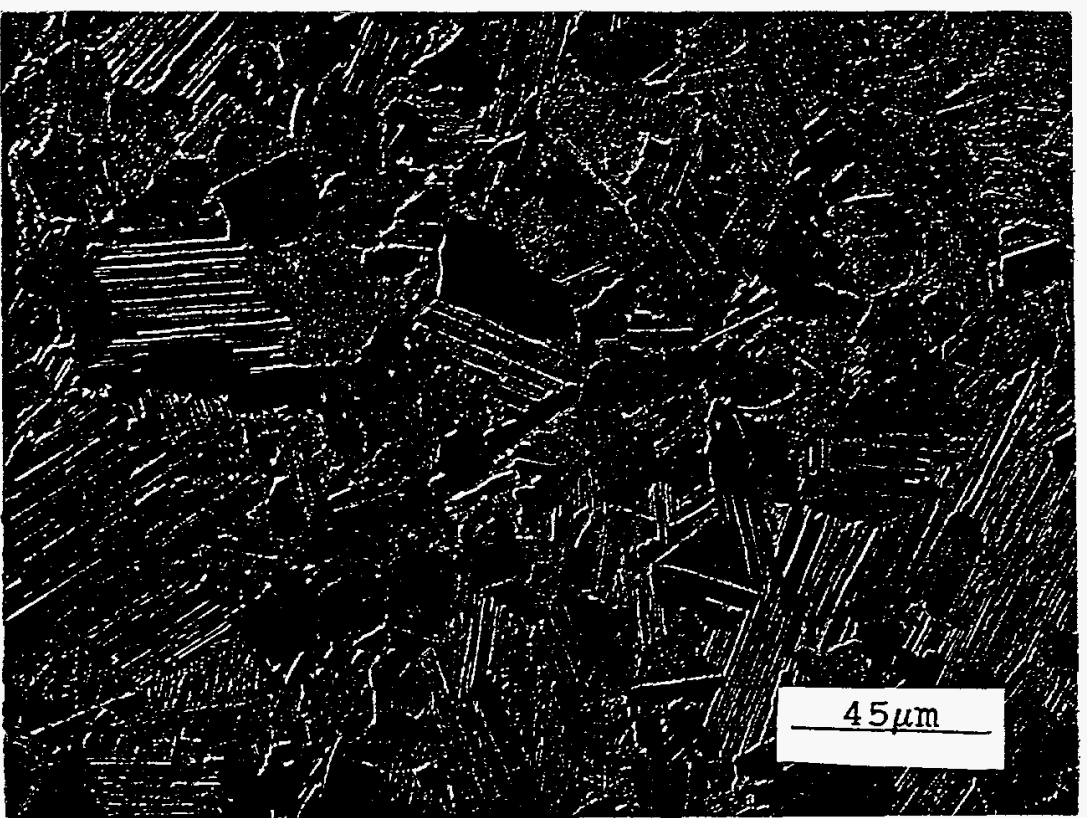

Figure 2 - Optical photomicrograph showing the near-lamellar microstructure of the heat treated $\left(1350^{\circ} \mathrm{C} / 2 \mathrm{hrs} / \mathrm{AC}+900^{\circ} \mathrm{C} / 6 \mathrm{hrs} / \mathrm{AC}\right) \mathrm{I} / \mathrm{M}$ Extrude + Forge $(\mathrm{TA}-163)$ sample. 


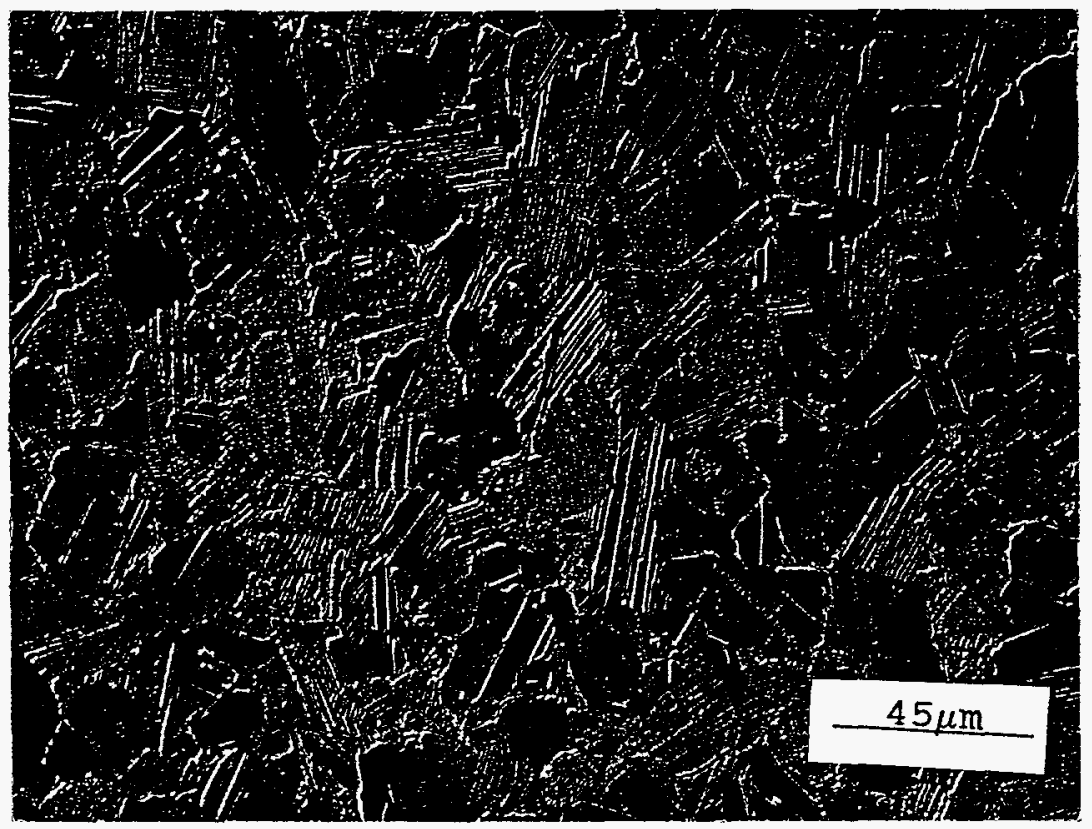

Figure 3 - Optical photomicrograph showing the near-lamellar microstructure of the heat treated $\left(1350^{\circ} \mathrm{C} / 2 \mathrm{hrs} / \mathrm{AC}+900^{\circ} \mathrm{C} / 6 \mathrm{hrs} / \mathrm{AC}\right) \mathrm{I} / \mathrm{M}$ two-step isothermally forged (TA-159) sample. 


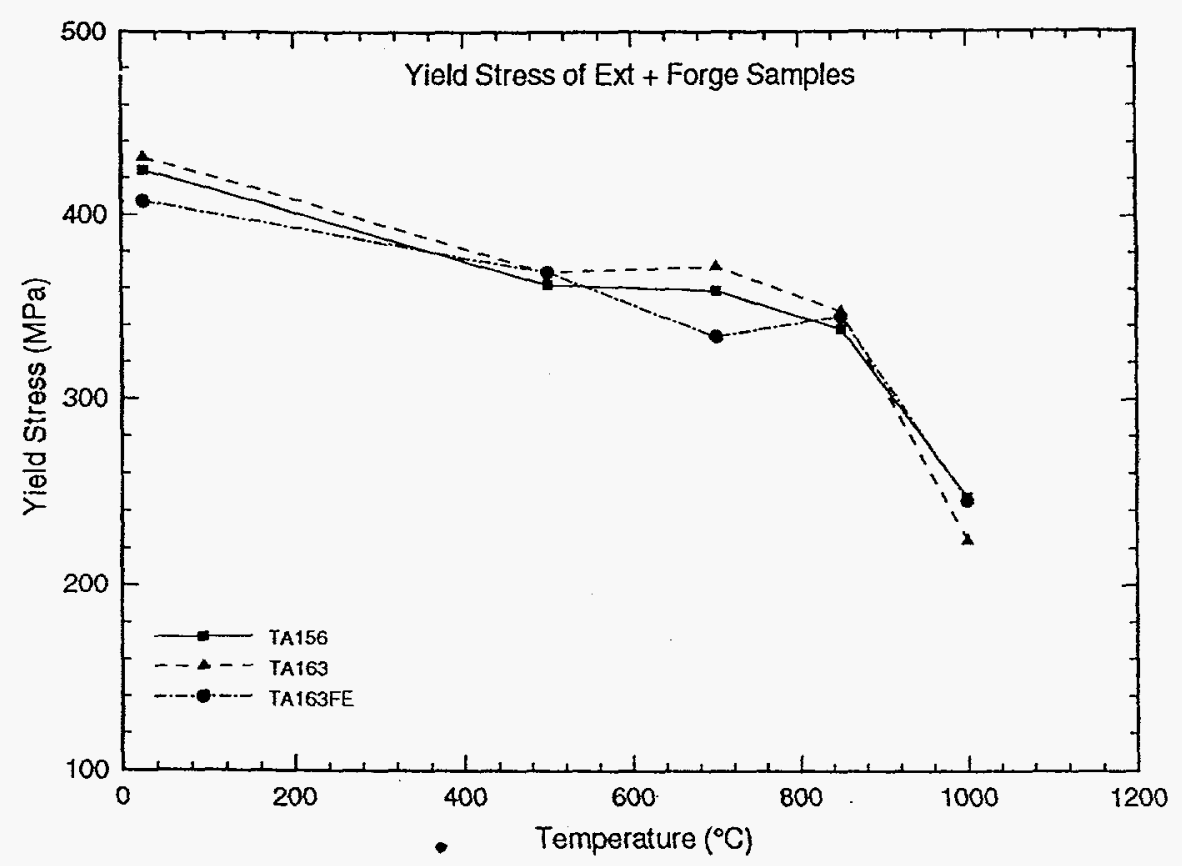

a.)

1

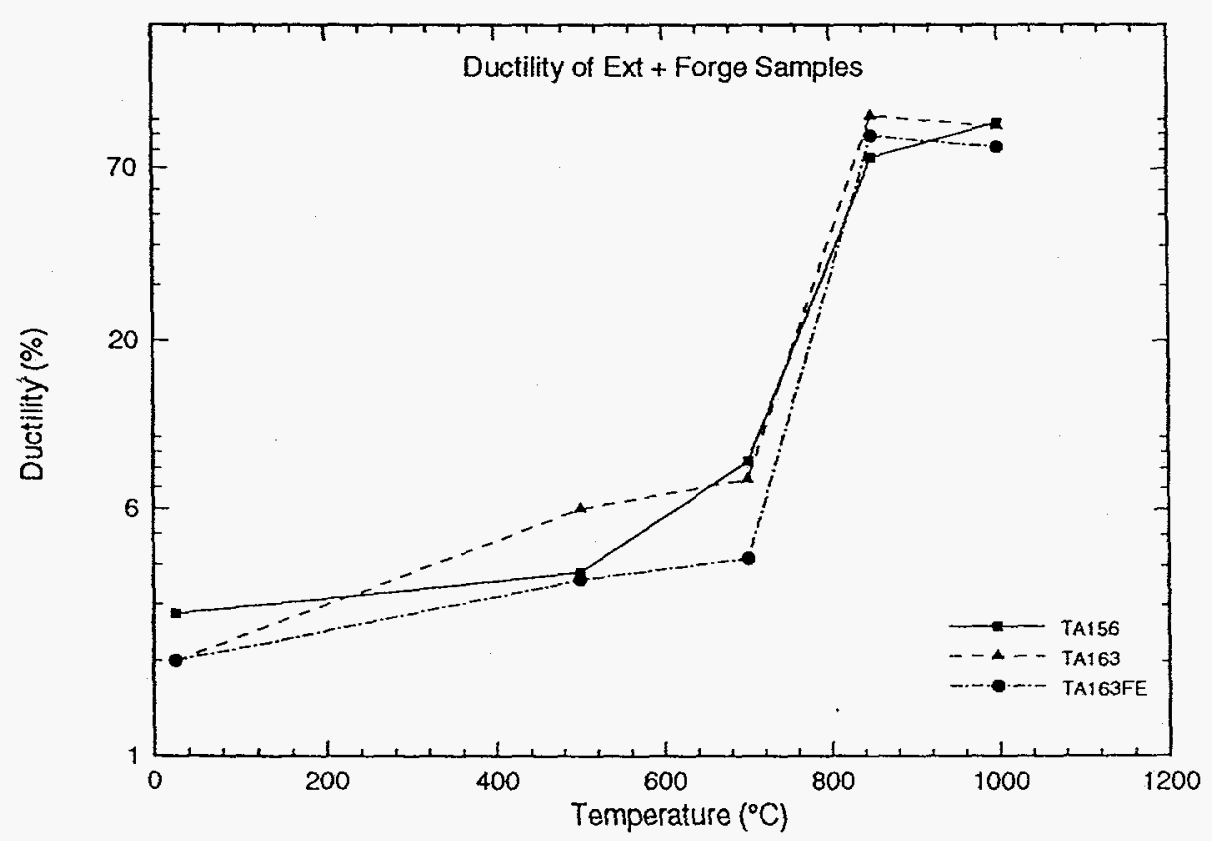

b.)

Figure 4 - Tensile properties of the $\mathrm{I} / \mathrm{M}$ and $\mathrm{P} / \mathrm{M}$ Extrude + Forge samples in the temperature range $25^{\circ}-1000^{\circ} \mathrm{C}$.

a.) Yield Stress

b.) Elongation 


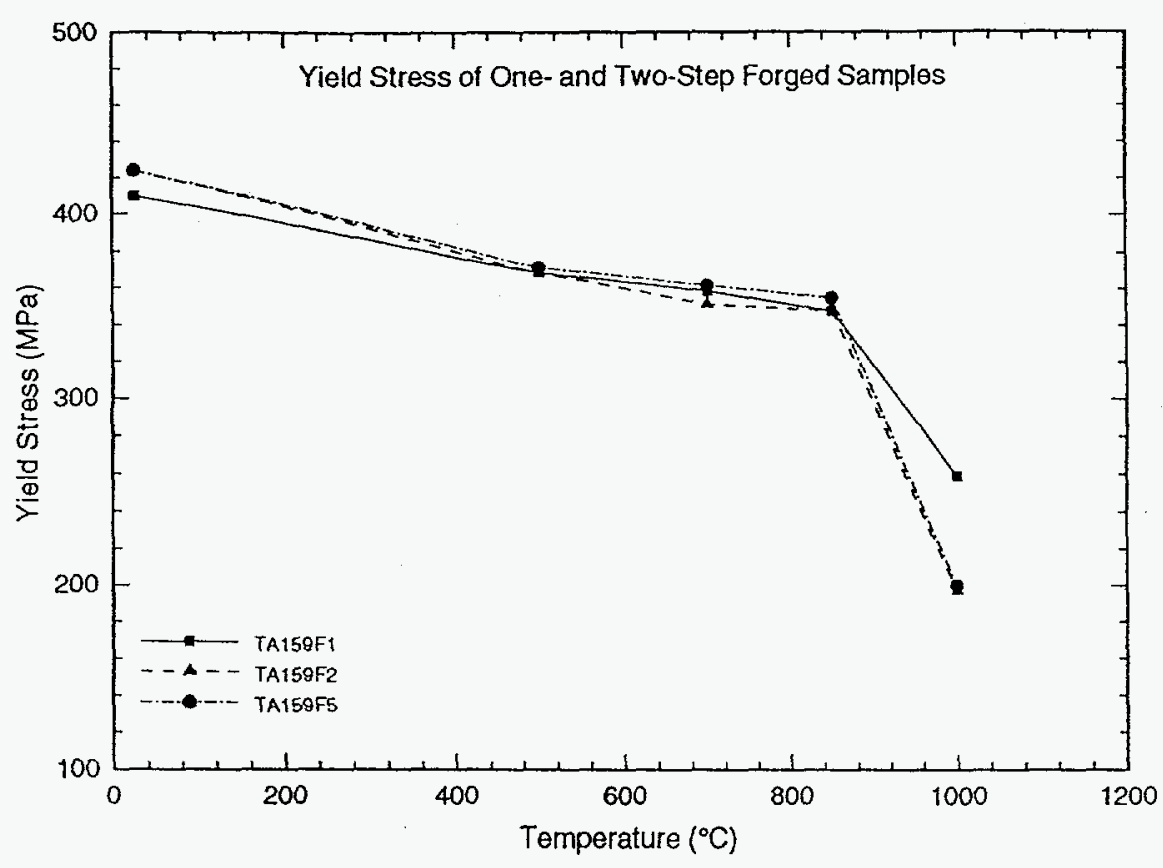

a.)

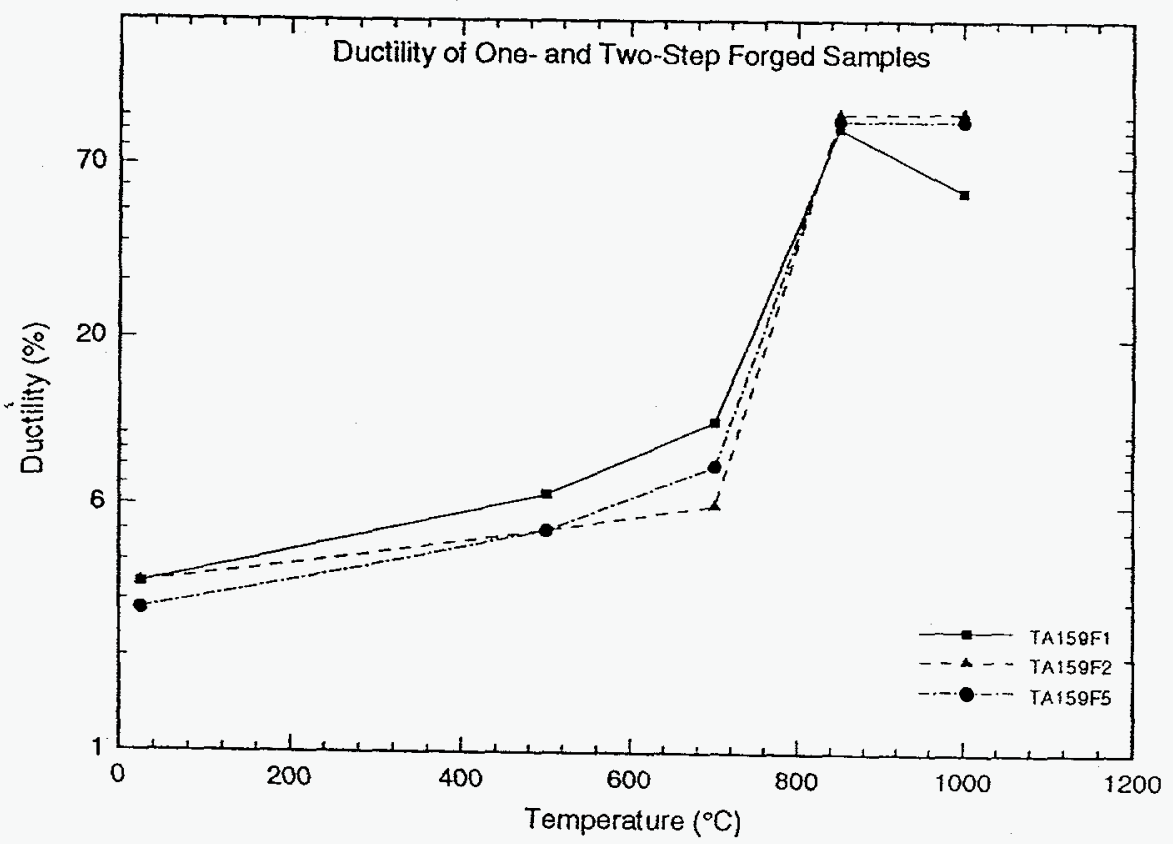

b.)

Figure 5 - Tensile properties of the I/M One-Step and Two-Step isothermally forge samples in the temperature range $25^{\circ}-1000^{\circ} \mathrm{C}$.

a.) Yield Stress

b.) Elongation 


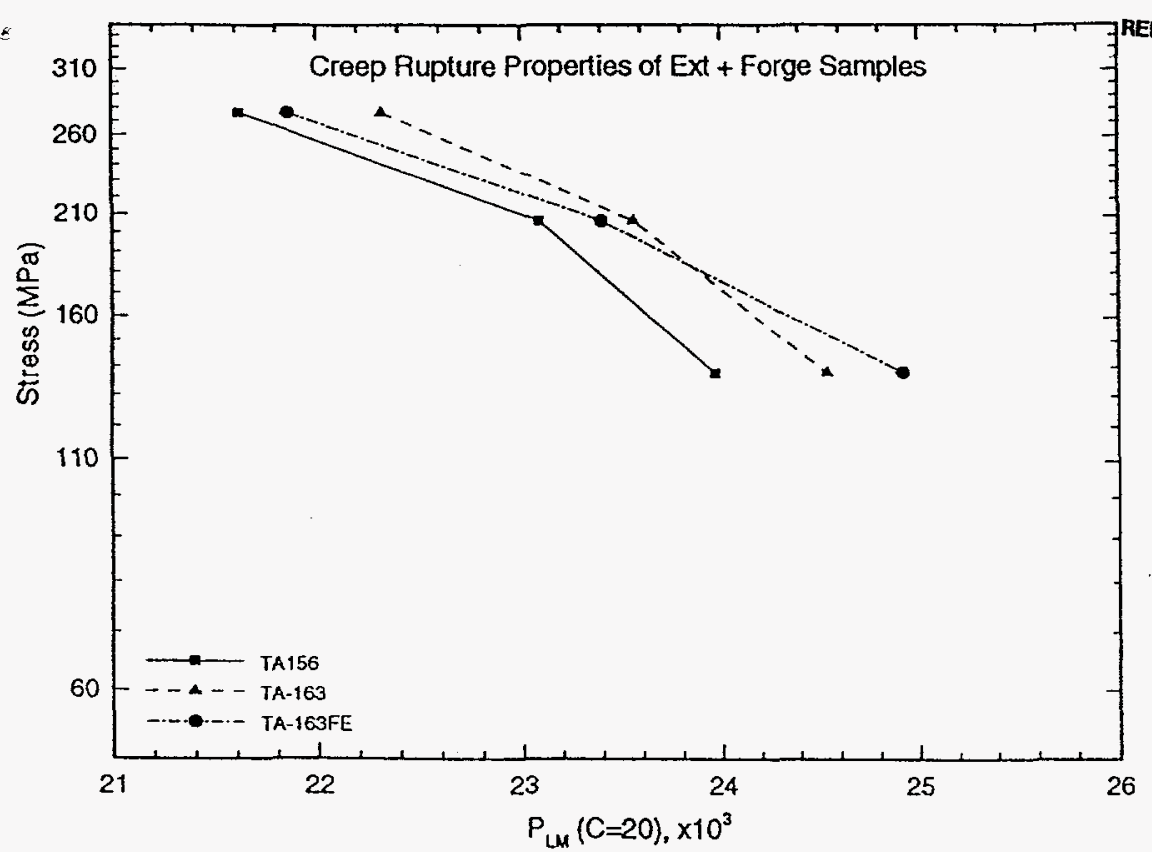

REPRODUCED AT GOVT EXPENSE \# 5

a.)

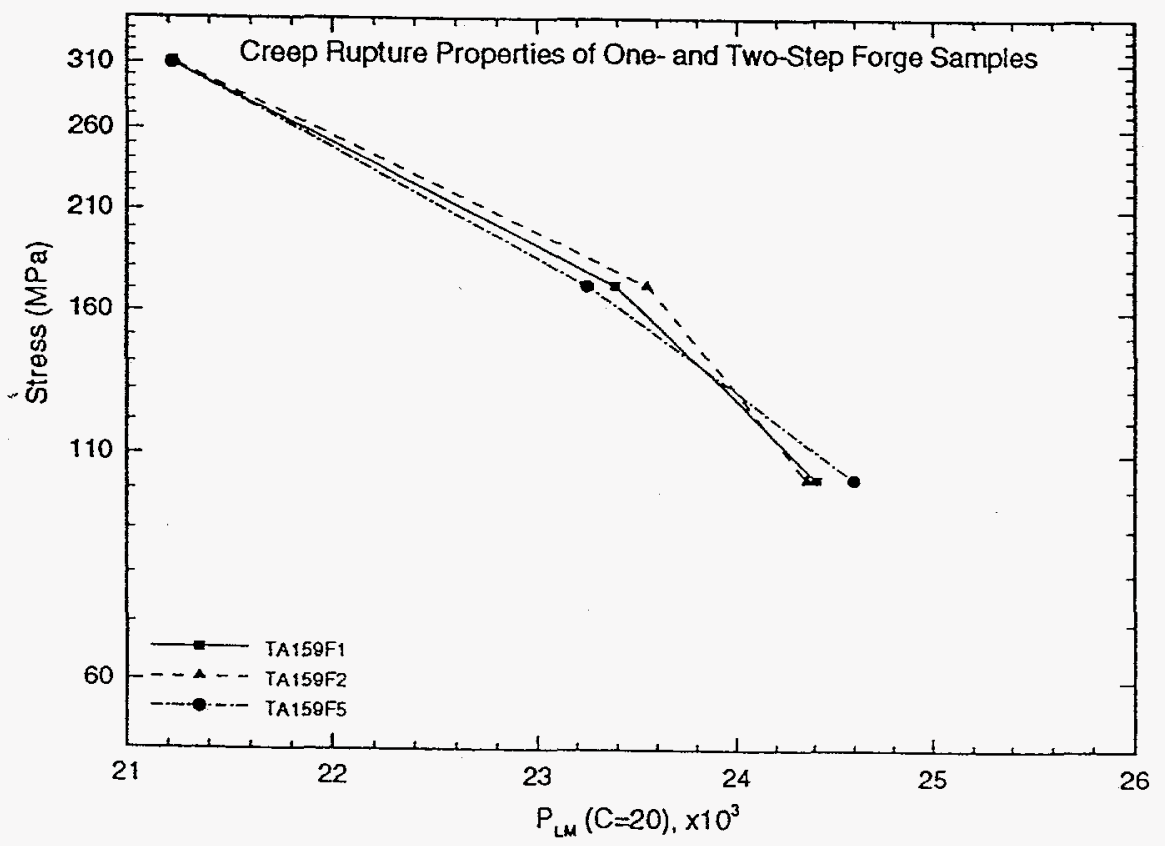

b.)

Figure 6 - Creep Rupture properties of the Extrude + Forge and the One-Step and Two-Step isothermally Forged samples in the temperature range $700^{\circ}-850^{\circ} \mathrm{C}$.

a.) Extrude + Forge $\mathrm{I} / \mathrm{M}$ and $\mathrm{P} / \mathrm{M}$ Samples

b.) One- and Two-Step Isothermally Forged I/M Samples 


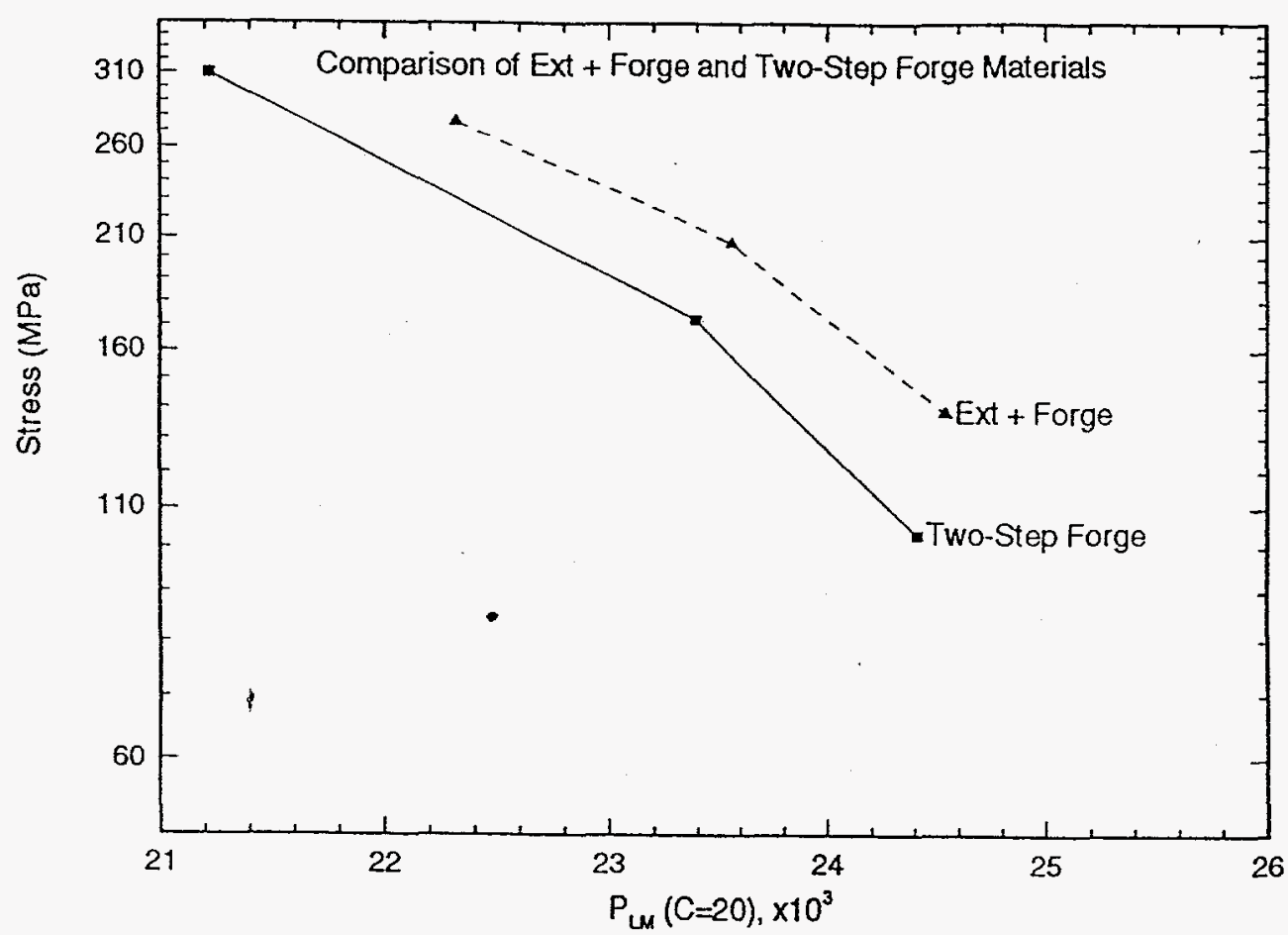

Figure 7 - Comparison of the creep rupture properties of the Extrude + Forge and the Two-Step Isothermally Forged Samples. Note, that the Extrude + Forged samples exhibit superior creep resistance at all stresses and temperatures evaluated. 